\title{
Research on the Development of ESP Teachers in Higher Vocational Colleges
}

\author{
Tianhua Zhang \\ Chengdu Agricultural College, Chengdu, Sichuan, 611130
}

Keywords: Development, ESP Teachers, Higher Vocational Colleges

\begin{abstract}
Student-centered ESP teaching principle determines ESP teachers should have a full range of comprehensive quality、solid English language skills and rich professional knowledge. At present, the development of ESP teachers in higher vocational colleges is lagging behind. ESP teachers should constantly improve their concepts and strengthen the teaching cooperation and training with the combination of English language and professional knowledge.
\end{abstract}

\section{Introduction}

The Higher Education Department of Education Ministry promulgated " the Basic Requirements of English Teaching in Higher Vocational Education". As the vocational English teaching objectives, teaching content and so made a clear request, vocational English teaching should be "to cultivate students practical use Language ability as the goal, highlighting the practicality of teaching content, practical and targeted. " However, there is a long time since the vocational education of English students from the actual career development needs of the phenomenon. On the one hand, vocational students not only have a strong demand for career development, but also hope that the foreign language content and the future career linked; on the other hand, vocational English teaching as a whole still continue the traditional foreign language teaching model, there are ESP and EGP "Two skin" phenomenon. Especially in the teacher building, due to the lack of double teacher cannot carry out training courses, leading to English and professional out of touch, is not conducive to the application of personnel training. According to the Ministry of Education portal statistics, in 2013 the country has a college entrance examination qualification of vocational colleges a total of 1266, of which 109 national higher vocational colleges, provincial higher vocational colleges, the vast majority of the majority are non-exemplary ordinary vocational colleges. These non-demonstrations of ordinary local vocational colleges in ESP teachers, teaching materials, teaching ideas and teaching facilities there are many restrictions. Such as the teaching objectives from the actual, lack of teaching teachers, teaching materials mess, teaching methods and other issues coexist. Therefore, based on the reality of local vocational teaching in English, it is imperative to construct ESP teaching teachers suitable for the characteristics of local vocational colleges.

\section{Research Objects}

Higher vocational English teaching consists of ESP and EGP, because ESP teaching lack of high-quality teachers, two teaching has been separated. EGP teachers have a foreign language background, master the language teaching methods, but the lack of relevant professional knowledge, and ESP teachers are related professional graduates, with strong professional knowledge, language teaching ability is relatively weak, classroom teaching methods to explain the professional vocabulary And the translation of professional articles mainly professional ESP teachers, especially the lack of outstanding teachers. Professional courses teachers or the main focus on their own professional courses, ESP course is only its "sideline", spent in the above energy is very limited. The self-assessment of the teaching effect of ESP teachers in higher vocational education; the teaching of ESP teachers, and the teaching of the teachers in the higher vocational education, including the teacher's educational background, title, teaching experience, related training, difficulties and suggestions encountered. The survey object is the twelve ESP teachers in four 
provincial vocational colleges.

\section{Research Methods}

In order to understand the current situation of ESP teaching in the local higher vocational colleges, this paper explores the way through the questionnaires and the depth interviews.

The Present Situation of ESP Teachers in Higher Vocational Colleges

\begin{tabular}{|c|c|c|c|c|c|c|c|c|c|c|c|c|}
\hline \multicolumn{2}{|c|}{ Gender } & \multicolumn{3}{|l|}{ Degree } & \multicolumn{2}{|l|}{ Profession } & \multicolumn{3}{|c|}{ Occupational Title } & \multicolumn{3}{|c|}{ Teaching Years } \\
\hline Male & Female & Bachelor & Master & Ph.D. & $\begin{array}{l}\text { Non-English } \\
\text { Major }\end{array}$ & $\begin{array}{l}\text { English } \\
\text { Major }\end{array}$ & Primary & Intermediate & Advanced & $\begin{array}{l}\text { Within } \\
5 \\
\text { Years }\end{array}$ & $\begin{array}{l}5 \text { To } \\
10 \\
\text { Years }\end{array}$ & $\begin{array}{l}\text { More } \\
\text { Than } \\
10 \\
\text { Years }\end{array}$ \\
\hline 11 & 1 & 5 & 6 & 1 & 10 & 2 & 1 & 8 & 3 & 2 & 7 & 3 \\
\hline
\end{tabular}

From the table we can see that the teaching of ESP in higher vocational education in the majority of men and more from the professional, which we investigate the nature of science and engineering disciplines. Teachers were young trend, the majority of teachers in the age of 10 years. After years of development, the local ordinary vocational school ESP teachers have improved, most teachers have master's degree and above. Most of the ESP teaching for young teachers aged 10 years and they may have insufficient teaching experience and professional knowledge. The survey found that ESP teachers lacked relevant training opportunities. In the 12 teachers surveyed, only 2 received relevant training, including one for domestic short-term training, one for study abroad, and the remaining teachers had no relevant training experience. In the teaching effect most of the teachers on their teaching ESP course teaching effect is not satisfied, the method used is "translation translation text, explain the exercises", student interest is not high. In the interview, the teachers believe that the biggest difficulty in teaching is the lack of English proficiency and language teaching ability, they are also in urgent need of relevant training. There are also many teachers that managers do not pay attention to professional English teaching.

At present, higher vocational ESP teaching mainly by the English language teachers or professional teachers to assume two types of teachers, but as ESP teachers have their own shortcomings. English language teacher is mainly engaged in the teaching of ordinary English courses. The language skills are solid and the language teaching experience is rich. However, as ESP teachers, teachers are not familiar with a professional business and lack of professional knowledge. Teachers themselves need to understand their professional language and vocabulary characteristics. A lot of time to consult a lot of information, and still cannot fully understand the professional needs of learners, teaching focus is still stuck in the lexical analysis of language and other language level, which cannot achieve the intended ESP teaching goals, and even mislead the learners. Professional teachers as ESP teachers, the advantage is familiar with the professional knowledge, understanding of the professional vocabulary and communication mechanism, but as a language teacher is the lack of relevant professional training, the content is often limited to professional knowledge and professional terms cannot be in specific teaching Reasonable training of language skills, it is difficult to English teaching theory in the classroom design arrangements in the mastery.

English language teachers and professional teachers as ESP teachers have their own strengths, but at the same time it is difficult to fully balance the English language and professional knowledge of effective teaching. The fundamental reason is that both English language teachers and professional teachers on the ESP teaching theory are not a thorough understanding, did not understand the fundamental requirements as ESP teachers. 


\section{The Development Strategy of ESP Teachers in Higher Vocational Colleges}

Change the Concept of ESP Teachers. With the globalization of the world, the degree of Chinese internationalization has been strengthened. Under the guidance of the "practical purpose and application for the purpose", ESP teachers should fundamentally understand that the cultivation of higher vocational education is the technology, Management, services and other areas of the higher application of specialized personnel. ESP teachers must understand the characteristics of ESP teaching, that is, emphasizing the needs of learners, learners as the center of the organization of teaching, pay attention to language knowledge and language use of the organic combination of students to develop language skills. Therefore, ESP teachers should pay attention to the classroom organization and classroom teaching research, starting from the needs of students, individualized, so that students more international competitiveness.

ESP teachers in higher vocational education should strengthen the concept of lifelong learning. In the era of knowledge explosion today, the rapid upgrading of knowledge, for English teachers, lifelong learning should be used as a habit. As Strevens (1988: 43) puts it: "Become an efficient ESP teacher, need more experience, extra training, extraordinary effort and new dedication than ordinary teachers." With the continuous development of professional and technical, new knowledge, new vocabulary, new educational ideas continue to emerge, English professional teachers only continue to learn and progress, always pay attention to the forefront of discipline development in order to become a qualified teacher, to guide students to synchronize with the world.

Achieve Teaching Cooperation. Teaching cooperation refers to the cooperation between English language and professional teachers. To strengthen the cooperation between English language teachers and professional teachers to learn from each other, learn from each other, which is effective in the use of teachers under the premise of ensuring the quality of teaching an effective way. Dudley - Evans, St John (1998) is divided into three levels, namely, cooperation, collaboration and team - teaching, which propose so - called cooperative teaching. ESP teaching first to start from the cooperation between the departments to reach a consensus, a clear curriculum in the syllabus requirements, and then foreign language teachers with professional teachers from the student needs to analyze the discussion of selected teaching materials, design course teaching and language Use, on the basis of this cooperation, you can collaborate, and then co-teaching.

In general, ESP teachers and public English teachers are different teaching departments, usually few opportunities for communication. Under the co-ordination of the school level, the establishment of a cooperative group or the establishment of specialized professional English teaching and guidance institutions to strengthen the interoperability of two types of teachers in the curriculum, curriculum convergence, selection of materials and so on to strengthen cooperation. Long-term engaged in foreign-related project work of enterprises with good English ability and related professional knowledge, the work process will often be combined with English knowledge and professional knowledge, is a better vocational school ESP source of teachers.

Conduct ESP Teachers Training. ESP teacher training is an effective way to improve the overall quality of ESP teachers. ESP teacher training should include language training and professional training two aspects. Language training refers to the improvement of English language skills, professional training refers to the teaching of professional knowledge structure, teaching methods and taught professional English style characteristics. Higher vocational colleges should strengthen the concern of the development of ESP teaching, increase the investment of ESP teachers training, conditions permitting the organization of ESP teachers into the company business internship or invite the backbone of the enterprise to train teachers, increase the school the level of cooperation in the enterprise to enrich the professional knowledge of the real source of corpus.

Support ESP Teaching from Colleges Policies. To take the initiative to fight for the school in the ESP teacher training, teaching materials and other aspects of policy support. On the one hand, focus on the use of public English teachers to train ESP teachers. It can be selected from the public English teachers interested in ESP teaching, interested in engaging in the research teachers especially young teachers to train and promote the transition to ESP teachers. Such as the opening of the ESP professional training courses on the public English teachers professional knowledge 
training, including professional terms and translation, basic theoretical knowledge. For the professional span of large (such as English teachers engaged in science and engineering ESP teaching), you can use English teachers and professional teachers one-on-one way of business learning. The Office of Academic Affairs supervises the training effect, which includes the training experience and achievements into the teacher's file as the basis for the year-end assessment and promotion of the duties. On the other hand, in the professional teachers in the selection of English good teacher to participate in English teaching classes or study the second degree of English teaching, to encourage professional teachers apply for foreign language professional qualification certificate and even qualified colleges and universities can select professional teachers to study abroad English, to improve the level of English teaching. And these need the school from the financial support, teacher training and assessment, personnel promotion system reform and other aspects of comprehensive consideration, the introduction of relevant policies.

\section{Conclusion}

ESP teaching is the development trend of English teaching in higher vocational education, and ESP teachers development is the key to restrict the development of ESP teaching. Qualified ESP teachers must have solid English language skills and rich professional knowledge, while focusing on the needs of learners. ESP teachers should continue to improve their knowledge structure, and strive to complete the transformation, and constantly improve English language skills and professional knowledge of the ESP teaching system. This is not only in line with the needs of teachers' own development, but also in line with the requirements of higher vocational college students, facing the diversification of the knowledge structure for the development of complex talents in higher vocational education.

\section{Acknowledgements}

Fund Project: This paper is part of the achievements of the project supported by the 8th China Foreign Language Education Funds of National Research Centre for Foreign Language Education in Beijing Foreign Studies University (No.ZGWYJYJJ2016B27) and the project supported by the 13th Five-Year Funds of National Agricultural and Vocational Education (No.2016-135-Y-247).

\section{References}

[1] Ni Yuhong. Research on EOP teaching in higher vocational colleges and its influencing factors [J] Foreign Languages, 2013, (4): 90 - 96.

[2] Tsai Jigang. ESP and the development of college English teaching in China[J]. Foreign Languages, 2004 (02).

[3] Liu Runqing. 21st Century English Teaching[J]. Foreign Languages Teaching and Research, 1996 (02).

[4] Liang Yan. ESP teachers professional development model [J]. Journal of Changchun University of Technology, 2005 (09).

[5] Xu Jing. Research on the development of ESP teachers in non - language majors in colleges and universities [J]. Journal of Zhongzhou University, 2010(06). 83. 